\title{
ディジタル制御電源を用いた衛星用低電力アークジェットスラスタの開発
}

\section{Development of Low-Power Arc-Jet Thruster for Satellite with Digital Control Power Supply}

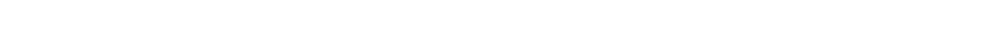 \\ Yukihiro OHNISHI, Satoshi UEDA, Michiaki INOMOTO and Takeshi FUKUDA
}

(Received August 29, 2005)

\begin{abstract}
Recently, miniaturization and light weight conversion of the satellite itself have become necessary. And high improvement of efficiency of the thruster has become necessary with the substantial restriction of the electric energy which it can use. In this study, conversion utilization of general solar light energy to electric power was proposed as the method of obtaining energy at outer space. We observed the arc-jet thruster because the thrust density was high even in the thrusters and the system and structure was relatively simple. Digital control power supply to electric power was developed in order to convert low, and to miniaturize and lighten the arc-jet thruster. As a result, discharge starting reproducibility with single power supply was good and we succeeded in stable arc discharge in the low electric current territory.
\end{abstract}

Key Words: Low-Power, Thruster, Digital Control Power Supply.

\section{1. 緒言}

通信, 放送, 測位, 気象観測等, われわれの生活において宇 宙衛星はもはや欠くことのできない技術となっている。宇宙 衛星の現在の主流は, $1 \mathrm{t}$ を越える大型多機能衛星となってい るが, 電子機器の小型化·高集積化技術の発展により, MEMS や LSI の混載デバイスからなる重量数 $\mathrm{kg}$ 程度の超小型衛星 (ナノサテライト) か現実的なものとなりつつある。超小型 衛星の利点として, 衛星本体およひ打ち上げに関するコスト の大幅な低減, 多数の超小型衛星の連携によって構筑される 分散・自律協調型衛星システムによる機能性・信頼性の向上 を挙げることができ，これを実現することができれば，宇宙 利用技術の質的変換をもたらすものと期待されている。

このような超小型衛星の実現において不可欠となるのが, 高効率推進機の開発である。小型軽量化はもちろんのこと, 使用できる電力量も大幅に制限されることから, 消費電力の 低減が重要な課題となる。ここで、各種推進機の性能を,推 力密度と比推力(単位時間あたりに消費する推進阂重量あた りに発生する推力)の関係を平面上にプロットした図を Fig.1 に示す。一般に推進機は次の 2 種類に大別される。1つは燃 料と酸化剂を燃焼室内で反応させ，火炎として発生した高温 高圧ガスをノズルを使って勢いよく噴射することで推力を得 る化学推進機である。このような推進機は推力が大きく，主 として地上からの打ち上げ用途に使用される。これに対して,

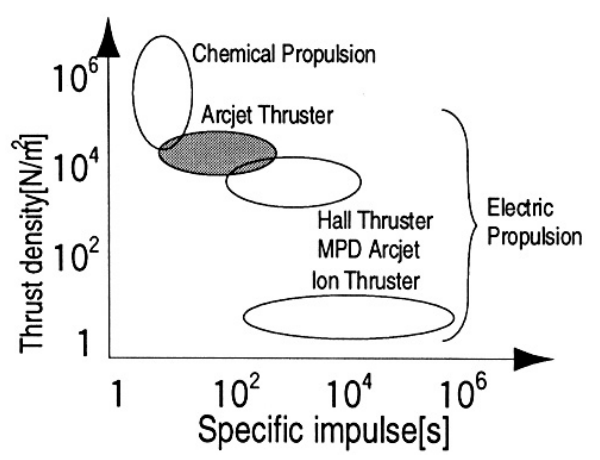

Fig.1 Propulsive characteristics of various thrusters.

アークジェットスラスタ, イオンスラスタ等に代表される電 気推進 ${ }^{11}$ は, 電力を推進剤に供給することで反力を得ようと する一種の外燃機関である2)。このような推進機か消費する 電力は, 一般的に宇宙空間で得られるエネルギー, すなわち 太陽光エネルギーを電力に変換して利用するものが多く, 化 学推進機のような瞬発的に強大な推力を発することはできな い。しかし, 比推力が大きいため, 衛星の姿勢制御や深宇宙 探査等の長期ミッションを目的とするならば，はるかに経済 的であり衛星用の推進機として適している。とりわけアーク ジェットスラスタは, システムや構造が比較的単純なため, 小 型軽量化に適しており, 超小型衛星用推進機として有力であ $3^{3)}$ 。

\footnotetext{
*大阪大学 工学研究科附属原子分子イオン制御理工学センター (广 567-0871 大阪府吹田市山田丘 2-1)

Center for Atomic and Molecular Technologies, Graduate School of Enginieering, Osaka University (2-1 Yamada-oka, Suita, Osaka 565-0871, Japan)
} 
ただし, 通常の直流アークジェットにおいては, 数 $\mathrm{kW}$ 以 上の電力を必要とするため, 超小型衛星用推進機として使用 するためには, 消費電力の大幅な低減が不可欠となる。また, 放電開始の際には数 $\mathrm{kV}$ 程度の高電圧パルスが用いられてお り, 推進機の小型軽量化のためには電源システムの単一化が 望まれる。本研究では, アークジェットスラスタに, 半導体 スイッチング素子を用いたディジタル制御電源を適用するこ とによる低電力化, 単一電源化, さらには制御性能の向上を 目的としている。

\section{2. 実験方法}

\section{1 実験装置}

実験装置の概略图を Fig.2 に示す。アークジェットスラス タは, 直径 $20 \mathrm{~cm}$ の円筒形真空チャンバ内に配置して実験を 行った。真空チャンバはロータリーポンプによって真空排気

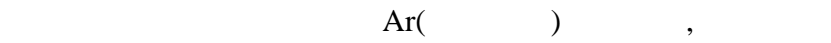
ウコントローラによって任意に流量を調節することができる。 アークジェットスラスタを動作させるための電力源としては, 従来のイグナイタ(高電圧パルス電源) +直流電源ではなく, 半 導体スイッチング素子を用いたディジタル制御電源を用いる のが本研究の提案である。本研究では, 半導体スイッチング 素子として IGBT を用いている。

また, 測定装置として高圧差動プローブ, 電流プローブを 用いて，任意の地点間の電圧及び，電流を測定している。こ れらの出力をオシロスコープで測定し, GP-IB でパーソナル コンピュータに取り込みデータ処理を行った。

\section{2 アークジェットスラスタ}

アークジェットスラスタは Fig.3に示すような構造をして おり, 同軸上に配置された針状の陰極 (2\%の酸化トリウムを 含むタングステン製) と円環状の陽極 (純モリブデン製) か らなる。また，電極間はセラミック製の絶縁体で隔離されて いる。

電極間に電圧を印加することで, 推進剤ガスガ絶縁破壊と ともに一部電離し，この電離により生じた荷電粒子が導電率 を高め, 一層, 放電が起きやすい状態になる。次に, 定常ア 一ク放電に移行することで推進剂ガスを加熱し，ノズル部で

Square wave si gnal $(\mathrm{PC} \rightarrow \mathrm{D} O \mathrm{O}$ boar $\mathrm{d})$

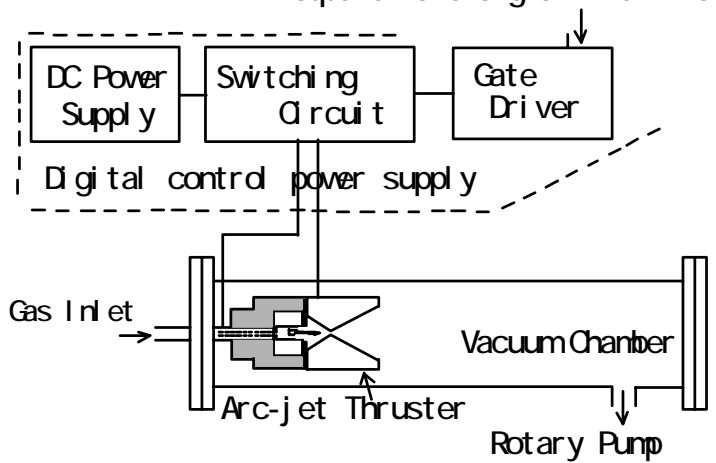

Fig.2 Schematic diagram of experimental equipment.
空力的に加速させることによって推力を発生するものであ る)。

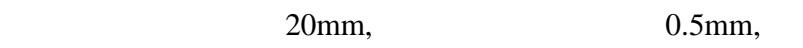
た電極間距離は 0 ～ $2.0 \mathrm{~mm}$ の間で調節できるが, 本研究では 実験的に比較的放電が良好な $1.0 \mathrm{~mm}$ に設定した。

\section{3 ディジタル制御電源}

本研究で開発したアークジェットスラスタ用ディジタル制 御電源回路を Fig.4に示す。パーソナルコンピュータにて半 導体スイッチング素子のゲートに印加する任意のスイッチン グ波形(方形波状電圧波形)を生成し, ディジタル入出力ボー ド, ディジタル信号入出力用ロジック回路, ゲート・ドライ ブ回路を経て, 半導体スイッチング素子に入力する。こうし て半導体スイッチング素子のオン/オフにより, アークジェッ トスラスタの電極間電圧を制御する。この回路は, ハーフブ リッジ型インバータ回路に類似した構造となっているが, 通 常のインバータ回路では出力側にトランスを使用して両極性 の交流電圧を発生させているのに対して, 本装置ではアーク ジェットスラスタの電極間で選択的に放電が発生するように, 片極性の電圧を発生する回路構成となっている。また, 通常 のインバータ回路ではサージによる過電圧の発生を抑制する ためにスナバ回路が装着されるのに対して, 宇宙空間では使 用できる電力量も大幅に制限されるため, 本装置ではスナバ 回路を省略することによって, 電源電圧を上回る高電圧を発 生させ, 放電開始効率の向上を目指している。

\section{4 実験手順}

本研究は, アークジェットスラスタ用の電源として開発し

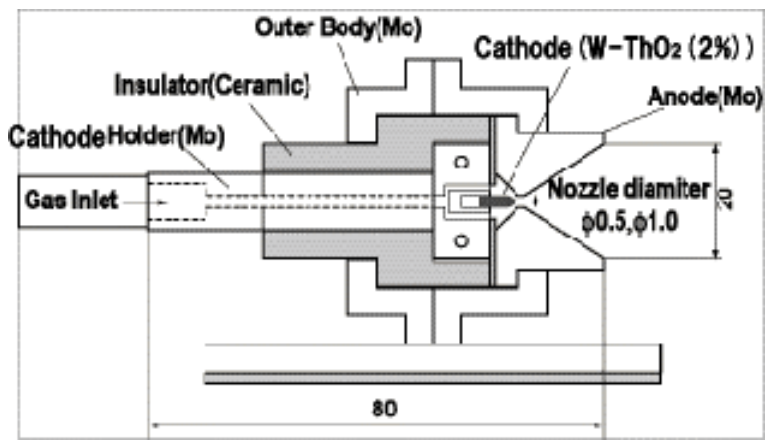

Fig.3 Construction of DC arc-jet thruster.

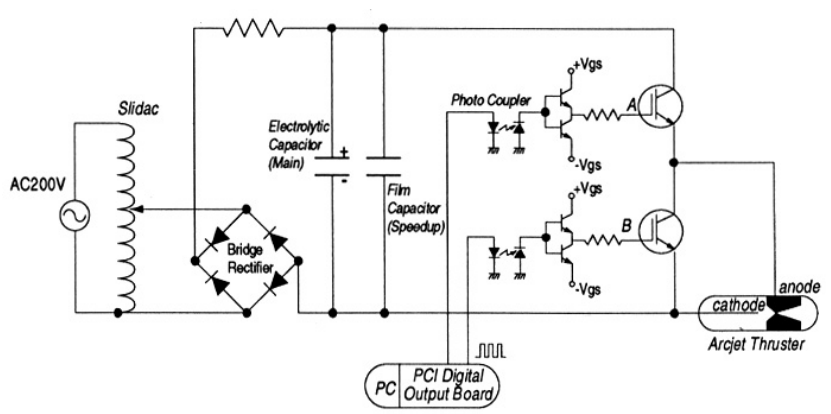

Fig.4 Digital control power supply. 
たディジタル制御電源を用いて, 次の実験を行った。

ディジタル制御電源によって, 片極性高周波電圧をアーク ジェットスラスタの電極間に印加し，イグニションを試み, 片 極性高周波電圧の周波数および電圧を変更することで，イグ ニションが可能な条件を確定する。また，この時の電極間放 電の詳細を検討する。

続いて，イグニション後に印加する電圧の周波数を変化さ せ，光の詳細を調べることでスラスタの消費電力，ひいては 推力を制御できる可能性を検討する。

\section{5 実験条件}

本研究で用いた実験条件を Table 1 に示す。

\section{3. 実験結果と考察}

ディジタル制御電源によって, 電源電圧 $200 \mathrm{~V}$ 、周波数 2.5MHz，デューティ比 0.25 の片極性高周波電圧をアークジ エットスラスタの電極間に印加した際の電流電圧波形を Fig.5 に示す。推進剂ガス流量は $0.3 \mathrm{mg} / \mathrm{s}$ である。

高周波電圧印加開始直後は, 電源電圧の 2 倍程度の 400〜 $500 \mathrm{~V}$ の高電圧が電極間に現れている。光の後, 電圧印加開 始から約 $250 \mu \mathrm{s}$ が経過した時刻に放電がイグニションが起 こり，放電が開始されている。このとき，電極間には 3〜6A 程度の電流が流れ始めると同時に，電極間に印加される電圧 は低下していることがわかる。

高周波電圧印加時における放電の詳細を検討する。Fig.6 に，電圧および電流の時間变化の詳細を示す。パーソナルコ ンピュータで生成した波形は周波数 $2.5 \mathrm{MHz}$, デューティ比 0.25 であるが, Fig.6 を見ると放電の一周期は $0.4 \mu \mathrm{s}$ であり，電

Table 1 Experimental conditions used in this study

\begin{tabular}{c|c}
\hline \hline Propellant gas & $\mathrm{Ar}$ \\
\hline Ar Flow rate & $0.3[\mathrm{mg} / \mathrm{s}] \sim$ \\
\hline Supply voltage & $\cdot 150 \sim 250[\mathrm{~V}]$ \\
\hline Frequency & $\mathrm{DC} \sim 2.5[\mathrm{MHz}] \cdot$ \\
\hline Pressure & $\sim 10[\mathrm{~Pa}]$ \\
\hline
\end{tabular}

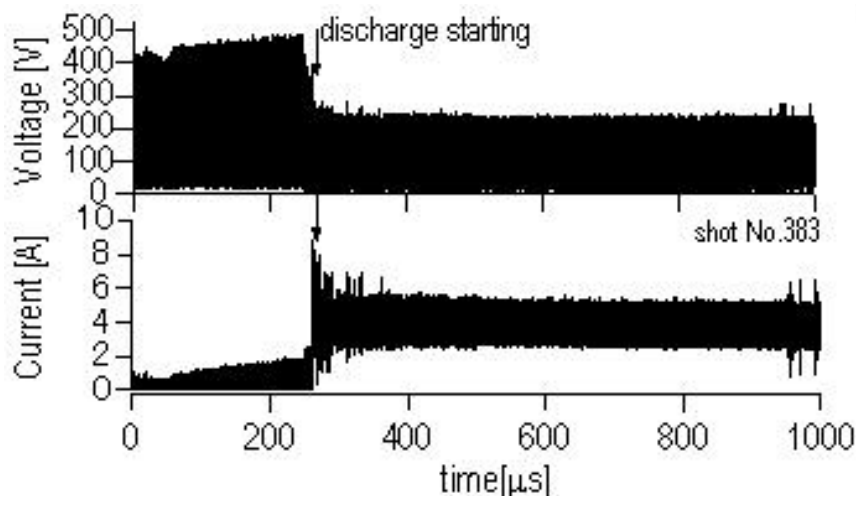

Fig.5 Anode-cathode voltage and current.
源電圧と同程度の高電圧が印加されている期間は $0.1 \mu \mathrm{s}$ と なっており，ディジタル制御回路は正常に機能している。電 圧の急激な増加と同期して電流の増加が確認できるが, 少の 後の電圧の急激な減少に対して, 電流は電圧減少後, 比較的 ゆっくりと減少していることがわかる。またこの電流の減少 に合わせるように電圧が徐々に増加していることから, ここ にアーク放電特性が見て取れる。

また, Fig.6においては, 周波数が $2.5 \mathrm{MHz}$ と非常に大きい ために，電流がゼロになる前に次サイクルの高電圧が印加さ れ, 兴れに伴う電流の増加が起こる。このような現象が繰り 返し起こるために, 結果として 3〜 4A 程度直流成分が常に現 れていることになる

次に, $2.5 \mathrm{MHz}$ の高周波で放電開始した後, 印加する電圧の 周波数を変化させた場合の電流電圧波形を Fig.7 に示す。

Fig.7(a)は 2.5MHz から $400 \mathrm{kHz}$ へ変化させた場合を示し, 同 图(b)は $2.5 \mathrm{MHz}$ から DC 八変化させた場合を示している。

Fig.7から, 印加する電圧の周波数を変化に伴って, 電極間 に流れる電流が大きく変化していることがわかる。このこと から, イグニション後の周波数とデューティ比を制御し, 間 欠放電させることで, 総消費電力を低減すると共に, 推力を 制御できる可能性を示唆している。

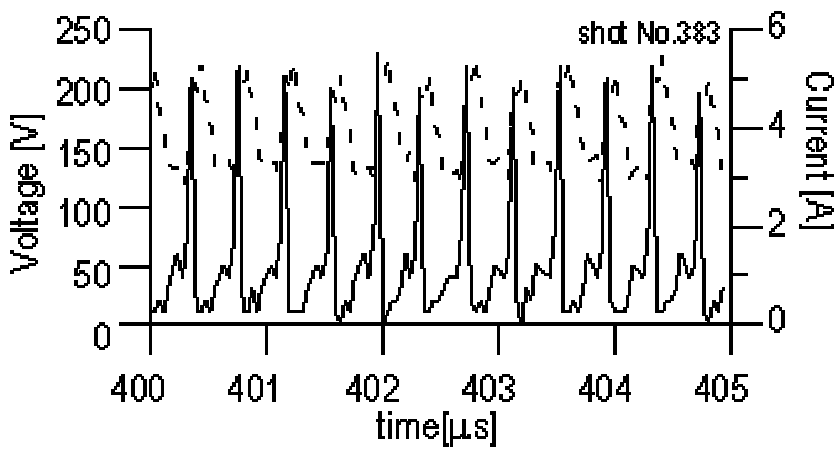

Fig.6 Detail of high-frequency discharge.

Voltage...solid line

Current...dashed line

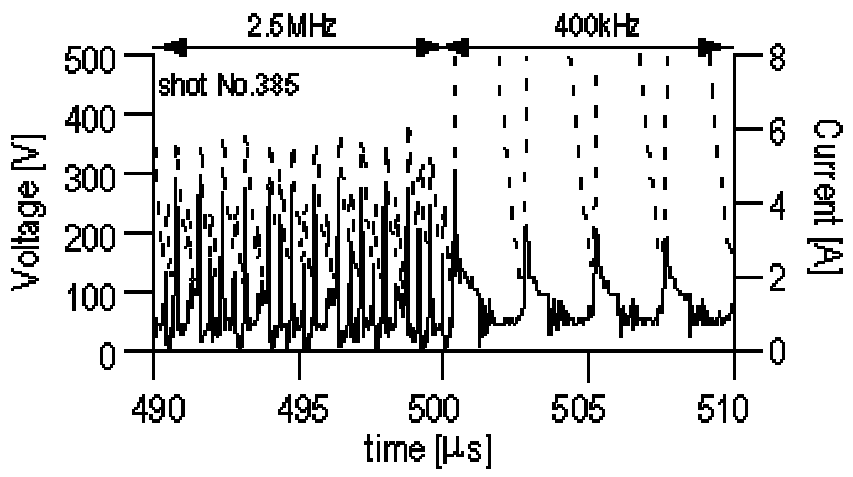

Fig.7 (a)Detail of high-frequency discharge.

Voltage...solid line Current...dashed line 
ディジタル制御電源を用いた衛星用低電力アークジェットスラスタの開発 (大西・上田・井・福田)

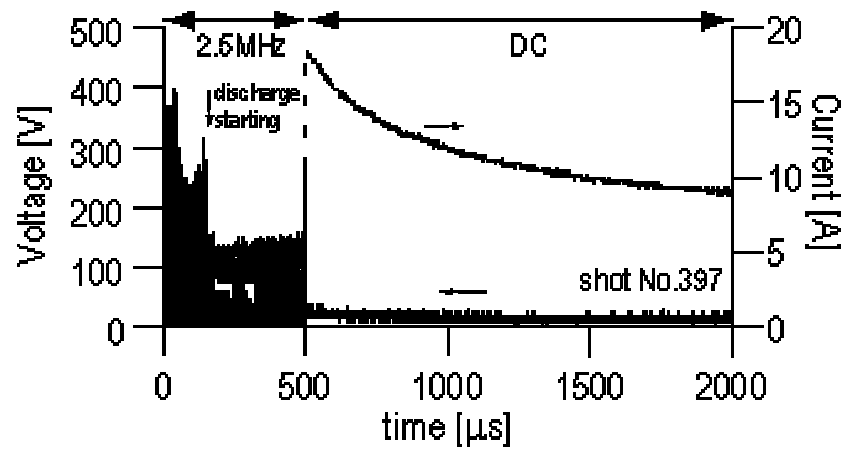

Fig.7 (b) Detail of high-frequency discharge.

Voltage...solid line

Current...dashed line

\section{4. 結言}

本研究では, アークジェットスラスタの小型・軽量化およ
び, 低電力化, ひいては制御性の向上を目指してディジタル 制御電源の開発を行った。ディジタル制御電源を用いること により, 電源の単一化すなわち, 小型·軽量化, および, 片極 性高周波電圧印加による再現性の良い放電開始, ならびに低 電流領域における安定なアーク放電の実現に成功した。また, イグニション後の周波数とデューティ比を制御することによ って, 放電特性を変化させ, 消費電力の低減および, 推力の より高精度な制御ができる可能性を示した。

\section{引用 文 献}

1) 吉川孝雄他 : プラズマ・核融合学会誌, 77 (2001) 763-792.

2) Sutton, G.P. : “Rocket Propulsion Elements, 6th Edition”, John Wiley and Sons, New York, 1992.

3) H.Horisawa and I.Kimura : Vacuum, 59 (2000) 106-117

4) 栗木恭一，荒川義博：” 電気推進ロケット入門”，東京大学出 版会, (2003). 